\title{
Prevalence and Correlates of Emergency Contraceptive Use in Transitional Albania
}

Citation for published version (APA):

Roshi, D., Italia, S., Burazeri, G., \& Brand, H. (2019). Prevalence and Correlates of Emergency Contraceptive Use in Transitional Albania. Das Gesundheitswesen, 81(7), E127-E132. https://doi.org/10.1055/s-0043-119085

Document status and date:

Published: 01/07/2019

DOI:

10.1055/s-0043-119085

Document Version:

Publisher's PDF, also known as Version of record

\section{Document license:}

Taverne

\section{Please check the document version of this publication:}

- A submitted manuscript is the version of the article upon submission and before peer-review. There can be important differences between the submitted version and the official published version of record.

People interested in the research are advised to contact the author for the final version of the publication, or visit the DOI to the publisher's website.

- The final author version and the galley proof are versions of the publication after peer review.

- The final published version features the final layout of the paper including the volume, issue and page numbers.

Link to publication

\footnotetext{
General rights Owners
rights.

- You may freely distribute the URL identifying the publication in the public portal. please follow below link for the End User Agreement:

www.umlib.nl/taverne-license

Take down policy

If you believe that this document breaches copyright please contact us at:

repository@maastrichtuniversity.nl

providing details and we will investigate your claim.
}

Copyright and moral rights for the publications made accessible in the public portal are retained by the authors and/or other copyright owners and it is a condition of accessing publications that users recognise and abide by the legal requirements associated with these

- Users may download and print one copy of any publication from the public portal for the purpose of private study or research.

- You may not further distribute the material or use it for any profit-making activity or commercial gain

If the publication is distributed under the terms of Article $25 \mathrm{fa}$ of the Dutch Copyright Act, indicated by the "Taverne" license above, 


\title{
Prevalence and Correlates of Emergency Contraceptive Use in Transitional Albania
}

\section{Pråvalenz und Korrelate des Gebrauchs von Notfallkontrazeptiva in Albanien}

\author{
Authors \\ Dajana Roshi ${ }^{1}$, , Salvatore Italia ${ }^{1}$, Genc Burazeri ${ }^{1}$, ${ }^{\text {, Helmut Brand }}{ }^{1}$
}

\section{Affiliations}

1 Department of International Health, School CAPHRI, Care and Public Health Research Institute, Maastricht University, Maastricht, The Netherlands

2 National Agency for Drugs and Medical Devices, Tirana, Albania

3 Faculty of Medicine, University of Medicine, Tirana, Albania

\section{Key words}

Albania, drug utilization, emergency contraceptive, health policy, levonorgestrel, socioeconomic background

\section{Schlüsselwörter}

Albanien, Arzneimittelgebrauch, Notfallkontrazeptiva, Gesundheitspolitik, Levonorgestrel, Sozioökonomischer Status

\section{Bibliography}

DOI https://doi.org/10.1055/s-0043-119085

Online-Publikation: 6.11.2017

Gesundheitswesen 2017; 79: e127-e132

(c) Georg Thieme Verlag KG Stuttgart · New York

ISSN 0941-3790

\section{Correspondence}

Dajana Roshi, MSc. Pharmacy

Republika e Shqiperise Ministria e Shendetesise

Pharmacovigilance Sector

Dibra street no. 359/1

1000, Tirana

Albania

dajana.roshi@yahoo.com

\section{ABSTRACT}

Objectives The two emergency contraceptive drugs ("morning-after pill”) ulipristal acetate and levonorgestrel are available without prescription in many European countries. In Albania, ulipristal acetate is not marketed yet and levonorgestrel has still prescription-only status. The objective of this study was to assess the prevalence and socioeconomic correlates of emergency contraceptive (EMC) use, collect sales figures, and gain information on the women's way of purchasing EMCs in postcommunist Albania.

Methods For this cross-sectional study, self-administered questionnaires were made accessible to women in Albania in March 2015 by hard copy or online via social networks. Women were asked about lifetime use and last year's use of EMCs, and if they purchased EMCs with or without a prescription. Additionally, pharmacies were contacted and asked about EMC sales figures. Results Of the 205 participating women, 80.5\% knew about the availability and use of EMCs, and $15.1 \%$ reported EMC use during the previous 12 months. The lifetime prevalence of use was $46.8 \%$. Although having prescription-only status in Albania, $96 \%$ of the women bought EMCs without a physician's prescription. Knowledge was significantly lower among the lower educated women and among women residing in small cities. Use of EMCs was significantly higher in women with a weaker financial background and, compared with small cities, in those from large or mid-sized cities. The 54 participating pharmacies ( $3 \%$ of all Albanian pharmacies) reported selling 11 EMCs on average per month. The use of EMCs may be estimated at 0.22 defined daily doses per 1,000 inhabitants per day. Compared to January 2015, EMC sales increased by $17 \%$ in February 2016.

Conclusions Compared to other European countries, the prevalence of EMC use seems to be higher in Albania. Use and knowledge of EMCs depend on socioeconomic characteristics. It is recommended to switch EMCs to non-prescription status in transitional Albania.

\section{ZUSAMMENFASSUNG}

Ziel der Studie Die 2 Notfallkontrazeptiva („Pille danach“) Ulipristalacetat und Levonorgestrel sind in vielen europäischen Ländern ohne Verschreibung erhältlich. Während in Albanien Ulipristalacetat nicht verfügbar ist, untersteht Levonorgestrel immer noch der Verschreibungspflicht. Ziel dieser Studie war, die Prävalenz sowie die sozioökonomischen Korrelate des Gebrauchs von Notfallkontrazeptiva zu erfassen, Verkaufszahlen zu erheben sowie Informationen über die Art des Zugangs der Frauen zu Notfallkontrazeptiva im post-kommunistischen Albanien zu ermitteln. 
Methodik Für diese Querschnittstudie wurden im März 2015 selbst auszufüllende Fragebögen an Frauen in Albanien verteilt oder über Internet mittels sozialer Netzwerke zugänglich gemacht. Die Frauen wurden gefragt, ob sie jemals oder während der letzten 12 Monate Notfallkontrazeptiva verwendet hatten, und ob sie das Notfallkontrazeptivum mit oder ohne Rezept erworben hatten. Zusätzlich wurden auch Apotheken kontaktiert und gebeten, ihre Verkaufszahlen zu Notfallkontrazeptiva zu übermitteln.

Ergebnisse Von den 205 Teilnehmerinnen waren 80,5\% über die Möglichkeit der Notfallkontrazeption informiert. 15,1\% hatten ein Notfallkontrazeptivum innerhalb der letzten 12 Monate verwendet. Die Lebenszeitprävalenz lag bei $46.8 \%$. Obwohl Notfallkontrazeptiva in Albanien verschreibungspflichtig sind, erwarben $96 \%$ der Frauen diese Mittel ohne ärztliche Verordnung. Frauen mit geringerer Bildung und Frauen aus Kleinstädten waren signifikant weniger über die Möglichkeit der Notfallkon- trazeption informiert. Der Gebrauch von Notfallkontrazeptiva war bei Frauen mit schwächerem finanziellen Hintergrund signifikant erhöht, ebenso wie bei Frauen aus mittelgroßen Städten und Großstädten (im Vergleich zu Kleinstädten). Die 54 teilnehmenden Apotheken (3\% aller albanischen Apotheken) gaben an, durchschnittlich 11 Notfallkontrazeptiva pro Monat verkauft zu haben. Der Gebrauch von Notfallkontrazeptiva kann grob mit 0,22 definierten Tagesdosen pro 1000 Einwohner und Tag geschätzt werden. Verglichen mit Januar 2015 wurden im Februar $201617 \%$ mehr Notfallkontrazeptiva verkauft.

Schlussfolgerung Im Vergleich zu anderen europäischen Ländern scheint der Gebrauch von Notfallkontrazeptiva in Albanien höher zu sein. Sowohl Gebrauch von als auch Wissen über Notfallkontrazeptiva hängen von sozioökonomischen Faktoren ab. Die Entlassung dieser Arzneimittel aus der Verschreibungspflicht ist in Albanien empfehlenswert.

\section{Introduction}

The issue of unwanted pregnancies is a relevant public health topic, as about $41 \%$ of all pregnancies worldwide and $44 \%$ of pregnancies in Europe have been reported by women to be unintended [1]. Especially among young adolescent women aged $15-19$ years, the majority of pregnancies may be unwanted [1], which might lead to higher abortion rates in this age group. The topics of unwanted (teen) pregnancies or the use of (emergency) contraceptives are also linked to socioeconomic factors [2-8]. Unplanned pregnancies are more likely among financially weaker women [2], younger women [2, 5], or lower educated women [4, 5]. In Finland, a lower use of emergency contraceptive (EMC) drugs was related to living in rural areas and to higher paternal education background [9]. A French study found a higher EMC use among higher educated women and those living in large cities [10].

An EMC can prevent from unintended pregnancy if taken quickly after unprotected sexual intercourse. Two active pharmaceutical ingredients are available in Europe for this purpose, levonorgestrel (LNG) with a single dose of $1.5 \mathrm{mg}$ and ulipristal acetate (UPA). To speed up access to EMCs, the European Medicines Agency recommended switching UPA to non-prescription status in November 2014 [11]. As of February 2017, LNG and/or UPA are freely available in many European countries [12,13].

Before 1990, contraceptives were generally banned in Albania. After the breakdown of the communist regime, Albania experienced a major political, social, and economic turmoil. In the past two decades, tremendous changes in lifestyle have taken place, which include also the attitudes towards and the use of pharmaceutical products. Two LNG-containing EMCs are currently available in Albania, Norlevo ${ }^{\circledR}$ (registered in January 2005) and Postinor- $2^{\circledR}$ (registered in March 2012). Both LNG-based EMCs haves still prescription-only status. UPA has been registered in May 2016 as a freely available EMC, but it is not marketed in Albania yet.

Data on EMC use in Albania is rather scarce. In this context, this study had two objectives: i) to assess the knowledge about EMCs and the prevalence and the socioeconomic correlates of EMC use in Albania.

ii) to provide figures for EMC sales and information on the women's way of purchasing EMCs.

\section{Material and methods}

\section{Study population and data collection}

This cross-sectional study was conducted in Albania over a period of 3 weeks in March 2015. To assess the prevalence of EMC use (within the last year; and lifetime use) and the women's socioeconomic background (age, place of residence, education, financial status), structured self-administered questionnaires were handed out to female students at 2 universities. Further questions such as knowledge about the possibility of emergency contraception with pharmaceuticals, way of purchase (with or without prescription, bought abroad) or if the women had encountered any problems when asking for an EMC prescription were also included in the questionnaire.

Additionally, pharmacies were also invited to provide data using another questionnaire. They were asked to report prices for EMCs and monthly sales figures for the 2 registered EMC brands (Norlevo ${ }^{\circledR}$, Postinor- $2^{\circledR}$ ) in Albania for the period January 2015 until February 2016, whether they would consider it to be common practice to sell EMCs without prescription, and if they had cases where women could not afford to buy an EMC.

In addition to the paper-based questionnaires, identical online versions were designed for the women and the pharmacies using google forms (https://www.google.al/forms/about/). The link was shared in social networks or sent by email to randomly chosen women and pharmacies. All data were collected anonymously or anonymized, if necessary.

\section{Statistical analysis}

For the statistical analysis, the SAS software package (SAS Institute Inc., Cary, NC, USA, version 9.3) was used. Bivariate associations 
were tested with Pearson $\mathrm{Chi}^{2}$ test or, in case of too small cell values of the contingency tables, with Fisher's exact test. Odds ratios (ORs) and their $95 \%$ confidence intervals $(\mathrm{Cl})$ were obtained from a multivariate logistic regression model (significance level: $\mathrm{p} \leq 0.05)$.

The participants were grouped into 3 age classes ( $16-24$ years, $25-34$ years, $\geq 35$ years). The following education levels were defined according to the participants' years they attended school:

Level 1:10-12 school years (high school education)

Level 2:13-15 school years (bachelor education)

Level 3:16-17 school years (master education)

Level $4: \geq 18$ school years (postgraduate studies)

The financial background was defined on the basis of self-perceived ability to meet the daily needs (cannot or can only meet the vital daily needs; can easily meet the daily needs).

The participants' place of residence was classified in 3 categories (Tirana, mid-sized cities with inhabitants between 50,000170,000 inhabitants, small cities with 20,000 inhabitants or less).

The study was approved by the Scientific Committee of the National Institute of Public Health in Albania. All participants gave their informed consent after being explained the aim and procedures of the study.

\section{Results}

\section{Sample structure and prevalence of knowledge about and use of emergency contraceptives}

Overall, 205 women aged 16-60 years from various Albanian regions participated in the survey (89 out of 89 distributed hard copy questionnaires were returned; 116 women submitted the completed questionnaire via Internet). Most of the participants attended school between $16-17$ years $(n=135) .10 \%$ of the women did some postgraduate studies ( $\geq 18$ school years), while $4 \%$ went to school for $10-12$ years only. Exactly 97 women said they would not be able to meet their daily needs ( $n=3$ ) or could only meet their vital daily needs ( $n=94)$, whereas 108 women reported that they would easily be able to meet their daily needs. The majority of the women $(n=151)$ resided in Tirana, Albania's largest city (with about 500,000 inhabitants). A further 22 women lived in mid-sized cities (Durres, Elbasan, Fier, Korça, Vlora). The remaining 12 participants came from 6 smaller or rather rural cities (Kashar, Kruje, Lezha, Perrenjas, Pogradec, Sarande,) with a population between 6,00020,000 inhabitants (missing values $n=20$ ). The exact sample structure is displayed in $>$ Table 1.

Overall, $80.5 \%$ (95\% Cl: 74.8-86.2\%) of the women knew about the possibility of avoiding unintended pregnancy by using an EMC. Exactly $15.1 \%$ (95\% Cl: 10.0-20.3\%) of the women reported having used EMCs at least once within the previous 12 months, and 46.8\% (95\% Cl: 39.8-53.9\%) took an EMC at least once in their lifetime. However, knowledge about and use of EMCs were not homogeneous across the socioeconomic strata.

Knowledge was highest among those aged $25-34$ years. Also, a significant difference was visible between the highest (85\%) and lowest (62.5\%) education level. Women from Tirana (83.4\%) were much better informed on the issue of EMCs compared with women living in mid-sized (68.2\%) or smaller cities (58.3\%).
The figures for the 1-year prevalence of use (18.6\%) and for lifetime use (53.6\%) were higher among women with problems to meet their daily needs, compared with women who perceived their financial situation as unproblematic ( 1 -year prevalence $=12.0 \%$; lifetime use $=40.7 \%$ ). Compared with urban areas, only few women living in small cities with 20,000 inhabitants or less used EMCs (no woman reported use within the last year, $8.3 \%$ reported lifetime use).

Of the 96 women who used EMCs, exactly 92 (95.8\%) said they bought it without a physician's prescription, although LNG-containing EMCs have still a prescription-only status in Albania. Some 13 women bought EMCs also or exclusively outside Albania (7 in Italy, 2 in Germany, 1 respectively in Macedonia, Greece, America, and Norway). With regard to affordability, 8 participants stated that they had hesitated to buy an EMC because of the high price, but all 8 reported having nevertheless finally bought the EMC.

A total of 5 women experienced some kind of problem with the physician in relation to the prescription of an EMC. For instance, two complained not being informed about side effects sufficiently or correctly, one got necessary information from the pharmacist instead of the physician, and one woman mentioned the physician was not available when she needed him.

\section{Correlates of emergency contraceptive use}

A logistic regression model ( $\triangleright$ Table 2 ) with 4 independent variables (simultaneously-adjusted model without interaction terms) revealed that a strong "predictor" of lifetime use of EMCs was a weaker financial background. Women who had difficulties in meeting their daily needs used almost twice as much EMCs (significant at $p=0.0382$ ) compared with women from a stable financial background $(\mathrm{OR}=0.53 ; 95 \% \mathrm{Cl}: 0.29-0.97)$. Also, the place of residence showed an association with EMC use, as, compared with Tirana, women living in mid-sized cities $(\mathrm{OR}=0.65 ; 95 \% \mathrm{Cl}: 0.24-1.74)$ and especially those living in small cities $(\mathrm{OR}=0.11 ; 95 \% \mathrm{Cl}$ : $0.01-0.91$; significant at $\mathrm{p}=0.0409$ ) used much fewer EMCs.

No logistic regression model for the 1-year prevalence of use and the knowledge about EMCs is presented at this place, as for both outcomes, the likelihood ratios of the SAS model fit statistics did not satisfy the criterion of $p \leq 0.05$.

\section{Sales figures}

54 Albanian pharmacies from 8 cities (Berat, Elbasan, Fier, Gjirokaster, Korça, Kukes, Pogradec, Tirana) reported sales figures for the 2 currently available LNG-containing EMC brands (Norlevo ${ }^{\circledR}$, Postinor- $2^{\circledR}$ ) in Albania for the period between January 2015 and February 2016 (one pharmacy submitted the data via Internet). Compared with January 2015, the number of sold packages slightly increased by $15 \%$ for Postinor- $2{ }^{\circledR}$ and $18 \%$ for Norlevo ${ }^{\circledR}$, respectively ( $\triangleright$ Fig. 1). In total, the 54 participating pharmacies sold 8,404 EMCs within 14 months ( $>$ Fig. 1). The price for Norlevo ${ }^{\circledR}$ ranged between 582 and 660 lek (€4.31-4.89). The price range for Postinor- ${ }^{\circledR}$ was 530-649 lek, which corresponds to €3.93-4.81 (exchange rate as of February 2017: 1 euro = 135 lek; for comparison: mean monthly gross income for employees at state authorities $=22,000$ lek, about $€ 163[14]$ ).

16 out of 54 pharmacies stated having had cases, where potential customers finally did not buy the EMC because it was not afford- 
- Table 1 Sample structure and prevalence of knowledge about and use of emergency contraceptives.

\begin{tabular}{|c|c|c|c|c|c|c|c|c|}
\hline \multirow[b]{3}{*}{ Total cohort } & \multirow{3}{*}{$\begin{array}{c}\mathbf{n} \\
205 \\
\end{array}$} & \multirow{3}{*}{$\begin{array}{r}\text { (\%) } \\
(100) \\
\end{array}$} & \multicolumn{6}{|c|}{ Prevalence rates in \% } \\
\hline & & & \multicolumn{2}{|c|}{$\begin{array}{c}\text { Knowledge about } \\
\text { EMCs }\end{array}$} & \multicolumn{2}{|c|}{$\begin{array}{c}\text { Use within the last } \\
\text { year }\end{array}$} & \multicolumn{2}{|c|}{$\begin{array}{l}\text { Use during } \\
\text { lifetime }\end{array}$} \\
\hline & & & 80.5 & & 15.1 & & 46.8 & \\
\hline \multicolumn{9}{|l|}{ Age class } \\
\hline $16-24$ years & 102 & $(49.8)$ & 75.5 & & 11.8 & & 38.2 & \\
\hline $25-34$ years & 83 & $(40.5)$ & 89.2 & $0.0303^{\mathrm{a}}$ & 16.9 & $0.2707^{a}$ & 56.6 & $0.0427^{\mathrm{a}}$ \\
\hline 35 years or older & 20 & $(9.8)$ & 70.0 & & 25.0 & & 50.0 & \\
\hline \multicolumn{9}{|l|}{ Education } \\
\hline $10-12$ school years & 8 & (3.9) & 62.5 & & 12.5 & & 50.0 & \\
\hline $13-15$ school years & 42 & $(20.5)$ & 66.7 & $0.0275^{b}$ & 14.3 & $0.9627^{b}$ & 23.8 & $0.0037^{b}$ \\
\hline 16-17 school years & 135 & $(65.9)$ & 85.2 & & 16.3 & & 54.8 & \\
\hline 18 school years or more & 20 & $(9.8)$ & 85.0 & & 10.0 & & 40.0 & \\
\hline \multicolumn{9}{|l|}{ Financial situation } \\
\hline Cannot or can only meet vital daily needs & 97 & $(47.3)$ & 78.4 & $0.4643^{a}$ & 18.6 & $0.1933^{a}$ & 53.6 & $0.0653^{\mathrm{a}}$ \\
\hline Can easily meet daily needs & 108 & $(52.7)$ & 82.4 & & 12.0 & & 40.7 & \\
\hline \multicolumn{9}{|l|}{ Place of residence } \\
\hline Tirana & 151 & $(73.7)$ & 83.4 & & 16.6 & & 49.0 & \\
\hline Mid-sized cities & 22 & $(10.7)$ & 68.2 & $0.0360^{\mathrm{b}}$ & 13.6 & $0.4001^{b}$ & 40.9 & $0.0221^{\mathrm{a}}$ \\
\hline Small cities & 12 & (5.9) & 58.3 & & 0.0 & & 8.3 & \\
\hline
\end{tabular}

EMC, emergency contraceptive; ${ }^{a} \mathrm{p}$-value derived from Pearson $\mathrm{Chi}^{2}$ test; ${ }^{\mathrm{b}} \mathrm{p}$-value derived from Fisher's exact test; Due to missing values, the strata may not add up to the total number of participants

- Table 2 Correlates of lifetime use of emergency contraceptives.

\begin{tabular}{|c|c|c|c|c|}
\hline & $\mathbf{n}$ & (\%) & $\begin{array}{l}\text { Lifetime use } \\
\text { of EMCs }\end{array}$ & $(95 \% \mathrm{Cl})$ \\
\hline \multicolumn{5}{|l|}{ Age class } \\
\hline $16-24$ years & 102 & (49.8) & Reference & \\
\hline $25-34$ years & 83 & (40.5) & 1.79 & $(0.88-3.63)$ \\
\hline 35 years or older & 20 & $(9.8)$ & 1.35 & $(0.46-3.97)$ \\
\hline \multicolumn{5}{|l|}{ Education } \\
\hline $10-12$ school years & 8 & (3.9) & Reference & \\
\hline 13-15 school years & 42 & (20.5) & 0.42 & $(0.08-2.32)$ \\
\hline 16-17 school years & 135 & (65.9) & 1.20 & $(0.25-5.68)$ \\
\hline 18 school years or more & 20 & $(9.8)$ & 0.48 & $(0.08-2.87)$ \\
\hline \multicolumn{5}{|l|}{ Financial situation } \\
\hline $\begin{array}{l}\text { Cannot or can only meet } \\
\text { vital daily needs }\end{array}$ & 97 & (47.3) & Reference & \\
\hline Can easily meet daily needs & 108 & $(52.7)$ & $0.53^{*}$ & $(0.29-0.97)$ \\
\hline \multicolumn{5}{|l|}{ Place of residence } \\
\hline Tirana & 151 & $(73.7)$ & Reference & \\
\hline Mid-sized cities & 22 & $(10.7)$ & 0.65 & $(0.24-1.74)$ \\
\hline Small cities & 12 & (5.9) & $0.11^{*}$ & $(0.01-0.91)$ \\
\hline
\end{tabular}

$C l$, confidence interval; EMC, emergency contraceptive; ${ }^{*}$ significant at $p \leq 0.05$; Due to missing values, the strata may not add up to the total number of participants

able. In sum, these 16 pharmacies estimated the number of respective cases at about 35 for a period of one month. Exactly 48 (88.9\%) pharmacies reported they thought it might be quite a common practice to sell EMCs also without a physician's prescription.

\section{Discussion}

The results of this study imply that the use of EMCs might be higher in post-communist Albania compared with other European countries. A 2004 study from France [10] found a lifetime prevalence of $31.7 \%$ (compared to $46.8 \%$ in Albania). In the United Kingdom [15], $7.3 \%$ of the women aged $16-49$ years (data published in 2005) used EMCs at least once during the last year (compared with $15.1 \%$ in Albania). In a Finnish study conducted in 1996, $15.1 \%$ of 17 -yearold girls reported to have used EMCs at least once during lifetime [16], which may be somewhat higher today, since in Finland, EMCs were switched to non-prescription status in 2002.

The sales figures presented in this study provided by 54 Albanian pharmacies (about $3 \%$ of the 1,800 pharmacies currently operating in Albania) may be extrapolated to a total yearly consumption of about 240,000 defined daily doses (DDDs) in Albania, corresponding to 0.22 DDDs per 1,000 inhabitants per day. This would be much higher than, for instance, in Denmark, where the consumption is on an almost stable level at 0.049 DDDs per 1,000 inhabitants per day since 2008. A lower consumption has also been reported for Estonia (stable for the period 2010-2014 at 0.06-0.07 DDDs per 1,000 inhabitants per day) and Montenegro (stable for the period 2012-2014 at 0.04 DDDs per 1,000 inhabitants per day). In Switzerland, the consumption of EMCs increased strongly after the switch to non-prescription status in 2002 to about 0.031 DDDs per 1,000 inhabitants per day in 2008, which is nevertheless still lower compared with Albania. In Germany, where EMCs are freely available since 2015, the consumption of EMCs seems to have reached a stable level of currently about 0.025 DDDs per 1,000 in- 


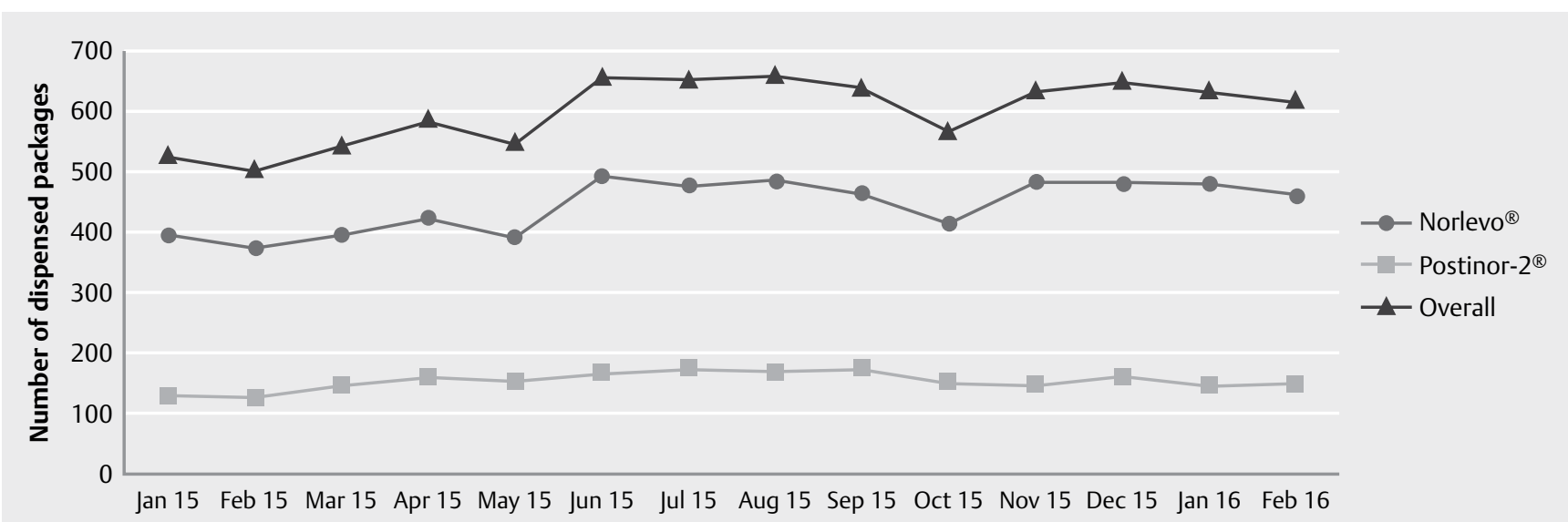

- Fig. 1 Number of emergency contraceptives dispensed ( $n=54$ pharmacies) per month.

habitants per day $[13,17]$. However, the estimation for Albania is rough and needs to be investigated on a larger data basis.

The use of EMCs is known to be predicted by socioeconomic factors. An Australian study [18] as well as an American one [19] showed that being not married increases the probability to use an EMC. A higher education was also linked to a higher use of EMCs in America [19]. In this Albanian study, EMC use was not associated with educational background. However, a higher use of EMCs among Albanian women correlated significantly with weaker financial background and living in an urban environment. The impact of financial background could possibly be explained by the fact that poor women may be able less to afford having children. A further explanation could be that poor women do not take normal contraceptive pills because of the price (which cost around 6-10 euros per cycle), but prefer to take a (cheaper) single dose of an EMC pill in case of need. According to the European consortium for emergency contraception, only $11.7 \%$ of Albanian women use modern contraceptive methods, compared with e. g., 67-76\% in Austria, Hungary, Denmark, France, or Germany [12]. Also, the perception of having fewer side effects by using a single-dose EMC instead of regularly using normal hormonal contraception could explain the high Albanian prevalence rates of EMC use. In this context it should be mentioned, that EMCs should, however, not be used as an ongoing method of contraception.

EMCs are not reimbursed in Albania and have therefore to be paid out of pocket. The hypothesis, that financial background could play a role is also strengthened by the fact that $4 \%$ of the surveyed women said they had hesitated to buy an EMC. Additionally, $30 \%$ of the participating pharmacies reported to recall a total of about 35 cases within a period of one month, where women could not afford to buy the EMC needed because of the high price.

With concern to the knowledge about EMCs, there seems to be a need to improve health literacy especially in rural Albania. This could be done, e. g. with TV commercials or by sending small groups of health professionals by state authorities, who could organize respective meetings with women living in rural areas.

This study has strengths and limitations. To our knowledge, this is the very first study presenting figures on the relevant topic of EMC use in Albania. Furthermore, it provides an updated view on
EMC sales figures over a period of 14 months provided by a relatively large number of pharmacies. However, one important limitation is the comparatively small number of participating women in this study. Also, the composition of the study cohort is not exactly representative for Albania, as e. $g$. the lower-educated strata and those living in more rural areas are underrepresented in this study. Moreover, the study included mainly students from urban areas, who may have a more stable financial background, compared with women residing in a rural environment. Furthermore, with respect to e. g. educational background or place of residence, the strata differ in size considerably, which may have reduced the significance of the results. In sum, the representativeness of the sample is limited and therefore, the findings should be interpreted with some reticence. For the future, more data from e. g. population based studies would be helpful.

\section{Conclusions}

It may finally be concluded that EMC-related health literacy needs to be improved in Albania, especially in rural areas. Furthermore, EMCs should be switched to free availability. By doing this, dispensing over the counter in pharmacies (which evidently is common practice in Albania) would be put on a legal basis and potential drug tourism (although unlikely) would be minimized.

\section{Funding}

This research did not receive any specific grant from funding agencies in the public, commercial, or not-for-profit sectors.

\section{Conflict of Interest}

The authors declare that they have no competing interests. 


\section{References}

[1] The European Society of Contraception and Reproductive Health (ESC) and the International Federation of Gynecology and Obstetrics (FIGO). (2011). The global epidemic of unintended pregnancies. Avalaible at: http://www.figo.org/sites/default/files/uploads/general-resources/ FIGO_ESC_Unwanted\%20Pregnancy\%20Slides.pdf; Accessed 10.11.2016

[2] Mallard SR, Houghton LA. Socio-demographic characteristics associated with unplanned pregnancy in New Zealand: implications for access to preconception healthcare. Aust N Z J Obstet Gynaecol 2013; 53: 498-501

[3] Thomas A. Policy solutions for preventing unplanned pregnancy (2012). Available at: https://www.brookings.edu/research/reports/ 2012/03/unplanned-pregnancy-thomas/; Accessed 16.11.2016

[4] Yago Simón T, Tomás Aznar C. Variables sociodemográficas relacionadas con embarazos no planificados en jóvenes de 13 a 24 años [Sociodemographic and clinical data predicting unplanned pregnancy in young 13 to 24 years, Spain]. Rev Esp Salud Publica 2014; 88 : 395-406 Spanish

[5] Font-Ribera L, Pérez G, Salvador ] et al. Socioeconomic inequalities in unintended pregnancy and abortion decision. J Urban Health 2008; 85: $125-135$

[6] Kozinszky Z, Sikovanyecz ], Devosa I et al. Determinants of emergency contraceptive use after unprotected intercourse: Who seeks emergency contraception and who seeks abortion? Acta Obstet Gynecol Scand 2012; 91: 959-964

[7] Al-Sahab B, Heifetz M, Tamim H et al. Prevalence and characteristics of teen motherhood in Canada. Matern Child Health J 2012; 16: 228-234

[8] Westall J. Poor education linked with teen pregnancies. BM] 1997; 314: 537

[9] Falah-Hassani K, Kosunen E, Shiri R et al. Emergency contraception among Finnish adolescents: awareness, use and effect of non-prescription status. BMC Public Health 2007; 7: 201
[10] Moreau C, Trussell ], Bajos N. The determinants and circumstances of use of emergency contraceptive pills in France in the context of direct pharmacy access. Contraception 2006; 74: 476-482

[11] European Medicines Agency. EMA recommends availability of ellaOne ${ }^{\circledR}$ emergency contraceptive without prescription (2014). Available at: http://www.ema.europa.eu/ema/index.jsp?curl = pages/ news_and_events/news/2014/11/news_detail_002223.jsp\&mid = WC0b01ac058004d5c1; Accessed 16.11.2015

[12] European consortium for emergency contraception. (2016). Available at: http://www.ec-ec.org; Accessed 19.03.2017

[13] Italia S, Brand H. Status of emergency contraceptives in Europe one year after the European Medicines Agency's recommendation to switch ulipristal acetate to non-prescription status. Public Health Genomics 2016; 19: 203-210

[14] Drejtoria e Përgijthshme e Tatimeve (General Directorate of Taxes). (2016). Available at: https://www.tatime.gov.al/sq-al/Media/ Njoftime/Pages/24072014_PagaMinimaleMaksimale.aspx; Accessed 02.01 .2017

[15] Marston C, Meltzer H, Majeed A. Impact on contraceptive practice of making emergency hormonal contraception available over the counter in Great Britain: repeated cross sectional surveys. BMJ 2005; 331: 271

[16] Kosunen E, Vikat A, Rimpelä M et al. Questionnaire study of use of emergency contraception among teenagers. BM] 1999; 319: 91

[17] Apotheke adhoc. IMS: 42 \% mehr "Pillen danach"(2016).Available at: http://www.apotheke-adhoc.de/nachrichten/nachricht-detail/ notfallkontrazeptiva-ims-nach-otc-switch-42-prozent-mehr-pilledanach/; Accessed 22.12.2016

[18] Hobbs MK, Taft AJ, Amir LH et al. Pharmacy access to emergency contraceptive pill: a national survey of a random sample of Australian women. Contraception 2011; 83: 151-158

[19] Daniels K, Jones J, Abma J. Use of emergency contraception among women aged 15-44: United States, 2006-2010. NCHS Data Brief 2013; $112: 1-8$ 